\title{
Aspectos das políticas indigenistas no Brasil
}

\author{
Aspects of indigenist policies in Brazil
}

\section{Aspects des politiques indigénistes au Brésil}

\author{
Aspectos de las políticas indigenistas en Brasil
}

\author{
Antonio Cavalcante Almeida ${ }^{1}$ \\ Recebido em 27/09/2017; revisado e aprovado em 29/11/2017; aceito em 29/11/2017 \\ DOI: http://dx.doi.org/10.20435/inter.v19i3.1721

\begin{abstract}
Resumo: O presente artigo investigou alguns documentos jurídicos do período colonial, do sistema imperial até o sistema republicano como: Cartas Régias, Decretos, Alvarás, Constituições e as principais declarações e convenções dos organismos internacionais de defesa dos direitos humanos. O objetivo é analisar como os povos indígenas foram tratados pelas legislações vigentes durante o processo de construção da sociedade e do Estado brasileiro. Assim, a pesquisa evidenciou que os povos indígenas conquistaram dispositivos constitucionais importantes a seu favor, principalmente nas últimas décadas do século XX.
\end{abstract}

Palavras-chave: Constituição; povos indígenas; leis.

Abstract: The present article investigated some legal documents from the colonial period, from the imperial system to the republican system such as: Royal Letters, Decrees, Permits, Constitutions and the major declarations and conventions of international organizations that defend human rights. The objective is to analyze how indigenous peoples were treated by the laws during the process of society formation and the Brazilian State. Thus, the research showed that indigenous peoples conquered important constitutional devices in their favor, especially in the last decades of the twentieth century.

Keywords: Constitution; indigenous peoples; laws.

Résumé: Le présent article a étudié certains documents juridiques de la période coloniale, du système impérial au système républicain tels que: Lettres Royales, Décrets, Permis, Constitutions et les principales déclarations et conventions des organisations internationales de défense des droits de l'homme. L'objectif est d'analyser comment les peuples autochtones ont été traités par les lois en vigueur au cours de la construction de la société et de l'Etat brésilien. Ainsi, la recherche a montré que les peuples autochtones ont conquis des dispositifs constitutionnels importants en leur faveur, surtout dans les dernières décennies du vingtième siècle.

Mots-clés: Constitution; peuples indigènes; lois.

Resumen: El presente artículo investigó algunos documentos jurídicos del período colonial, del sistema imperial hasta el sistema republicano como: Cartas Regias, Decretos, Alvarás, Constituciones y las principales declaraciones y convenciones de los organismos internacionales de defensa de los derechos humanos. El objetivo es analizar cómo los pueblos indígenas fueron tratados por las legislaciones vigentes durante el proceso de construcción de la sociedad y del Estado brasileño. Así, la investigación evidenció que los pueblos indígenas conquistaron dispositivos constitucionales importantes a su favor, principalmente en las últimas décadas del siglo XX.

Palabras clave: Constitución; pueblos indígenas; leyes.

\section{INTRODUÇÃO}

Ao longo de quase dois séculos de história de independência do país, as Constituições brasileiras foram representativas não dos anseios dos diversos segmentos sociais historicamente excluídos da sociedade nacional (indígenas, negros, mulheres, pobres e outros), mas dos interesses das classes dominantes. A exclusão social e a negação de direitos sociais básicos sempre foi o tom da elite política vigente, uma vez que o projeto de poder estava pautado numa visão fundamentalmente discriminatória e de negação dos direitos socioculturais dos povos originários.

\footnotetext{
${ }^{1}$ Instituto Federal Catarinense, Campus Luzerna, Santa Catarina, Brasil.
} 
Portanto toda a história de enfrentamento entre colonizador e ameríndio tem sido uma tragédia do ponto de vista sociocultural, econômico e político para as culturas locais.

A visão eurocêntrica presente na condução da vida política, econômica, religiosa e cultural do Brasil, desde o início da colonização, no século XV, teve, nos sucessivos textos jurídicos adotados, o seu equivalente etnocêntrico e racial. Isto é, não se contentando apenas com a disseminação da ideologia do eurocentrismo, a sociedade brasileira haveria de ser essencialmente "branca", "católica" e ocidentalizada se quisesse dar certo como nação.

Assim, quase todas as constituições nacionais, desde o ano 1891, tratam do processo de integração e assimilação do "silvícola", "habitante da selva" à sociedade nacional. Portanto, a consecução do projeto de homogeneidade racial e cultural como herança colonial foi, sob o ponto de vista político, indispensável para a construção da nova Nação brasileira que apenas seria viável caso lograsse atingir uma pretensa unidade nacional.

A legislação imposta aos povos indígenas foi, durante muito tempo, assinalada pela visão conservadora, homogeneizadora e defendeu os interesses dos colonizadores, em detrimento das populações indígenas que habitavam as terras brasileiras há muitos séculos. Assim, qual era o lugar do índio dentro da sociedade e no ordenamento jurídico desde a colonização? Em que medida a evolução das legislações indigenistas respeitavam a questão dos direitos territoriais e ancestrais dos indígenas?

Em virtude dessas e de outras questões provocadoras, este artigo aborda fundamentalmente a aplicação de algumas leis indigenistas alicerçadas em alguns documentos jurídicos relevantes no período colonial e, igualmente, analisa alguns aspectos significativos da fase imperial e as contribuições recentes da Constituição Federal de 1988 (CF/88) no tocante à questão indígena. Além do mais, foram apresentados alguns documentos internacionais importantes endossados pelo estado brasileiro em relação às populações tradicionais e indígenas. Assim, são eles a Convenção 169/1989 da Organização Internacional do Trabalho (OIT), e da Declaração das Nações Unidas sobre os Direitos dos Povos Indígenas (ONU, 2008).

\section{POLÍTICA E ASPECTOS DA LEGISLAÇÃO INDIGENISTA NO BRASIL}

\subsection{Aplicação das leis portuguesas, no Brasil, no período colonial}

Antes de tudo, essa história, já contada e recontada, é importante relembrar que Portugal, país com localização geográfica privilegiada para o Oceano Atlântico, funcionava como entreposto comercial marítimo desde o século XIII e, durante o século XV, transformou-se em grande centro de pesquisa naval na Europa. Assim, passou a explorar o oceano na busca de expansão ultramarina, com o fim de ampliar seus lucros por meio da conquista de novos territórios além-mar (SOUZA FILHO, 2010).

De acordo com Perrone-Moisés (1992), não existiu uma legislação indígena especificamente brasileira, independente do ordenamento jurídico português. Contudo, na ausência de tal direito colonial, o Brasil era regido pelas leis da metrópole portuguesa. Conforme a autora:

Não existiu um direito colonial brasileiro independente do direito português. O Brasil era regido basicamente pelas leis que a metrópole (compiladas nas Ordenações Manuelinas e, a partir de 1603, nas Ordenações Filipinas), acrescidas de legislação específica para questões locais. Na colônia, o principal documento eram os Regimentos dos governadores-gerais. O rei os assinava, assim como às Cartas Régias, Leis, Alvarás em formas de lei e Provisões 
Régias, auxiliado por corpos consultivos dedicados a questões coloniais. O primeiro desses conselhos foi a Mesa de Consciência e Ordens, criado em 1552. Seguiram-se o Conselho da Índia (1603) e seu sucessor, o Conselho Ultramarino (1643). Estes emitiam pareceres que podiam, e costumavam ser, sancionados pelo rei, passando a ter valor legal. Na colônia, os governadores-gerais emitiam Decretos, Alvarás e Bandos, aplicando a legislação emitida pela Coroa. Para o exame de questões específicas que exigiam conhecimentos locais de que a metrópole não dispunha, o rei ordenava a formação de Juntas (compostas de autoridade coloniais e religiosas), entre as quais a mais importante era a Junta das Missões, cujas decisões deviam ser-Ihe enviadas para apreciação e eventual aprovação. O que mais chama atenção nos documentos legais relativos à questão indígena é o fato de disposições emanadas diretamente da Coroa referirem-se em muitos casos a questões bastante específicas e locais tanto quanto os atos administrativos coloniais. (PERRONE-MOISÉS, 1992, p. 116-7).

No que tange à questão da legislação colonial lusitana, Perrone-Moisés afirma que ela era contraditória, oscilante, hipócrita, visto que era pouco discutida e consequentemente menos elaborada do que nas colônias espanholas a exemplo das Leis das Índias.

No tocante a essa contradição, Souza Filho (2010, p. 54) afirma que: "a repetição com que se dá a proibição da escravidão dos índios, e as exceções que as acompanham, revelam a prática constante da ilegalidade". De fato, os documentos historiográficos mostram a dificuldade que sempre tiveram os portugueses de impor um regime de trabalho às populações locais a ponto de importar escravos de outras regiões. Conforme Carneiro da Cunha (1992), a escravidão dos índios foi extinta diversas vezes, em particular no século XVII e no século XVIII.

De acordo com Thomas (1982), os primeiros esforços do governador Tomé de Sousa, em relação à liberdade dos índios durante seu governo, podem ser observados nas seguintes diretrizes do Regimento de 1549:

(1) Estabelecer a segurança e a paz da terra, mediante a vitória e a sujeição completa sobre as tribos índias revoltadas ou inimigas e sobre os seus aliados, os franceses; (2) Intensificar os esforços para proteção dos indígenas aliados dos portugueses, contra a espoliação e escravização e, em especial, acelerar a civilização e cristianização dos índios, mediante a fundação sistemática de aldeias; (3) Estabelecer um contato estreito e amistoso com os jesuítas, como pioneiros da política indigenista real, e sustentar as suas obras com apoio material. (THOMAS, 1982, p. 74).

A política indigenista adotada era de "proteção" para os aliados e de "guerra aberta" aos índios arredios ao método de colonização. Entretanto, com base nesse princípio, a escravidão indígena era permitida e justificada nas condições de "guerra justa" contra os grupos revoltosos até meados do século XIX. As expedições colonizadoras no século XIX, na província do Paraná, foram fundamentalmente baseadas no princípio da exploração dos territórios "inóspitos" (havia o discurso por parte das autoridades de vazio demográfico regional) e na política de concentração de pessoas num único lugar, visto que o autóctone era considerado um ser humano (com capacidade de salvação da alma) pela igreja e haveria de ser aldeado para integrar a sociedade religiosa.

No período colonial, a legislação não garantia efetivamente os direitos dos povos nativos, aliás, não houve interesse por parte da Coroa lusitana em resguardar o direito à liberdade e à igualdade de todos os índios, apenas àqueles em comunhão com o rei. É bom dizer que, nos primeiros séculos da colonização portuguesa, o direito português predominante, sobretudo nas colônias, era baseado nas Ordenações Manuelinas (1514) e, posteriormente, nas Leis Filipinas (1603), como já dito anteriormente. Entretanto, não havendo um direito genuinamente portu- 
guês para o indigenato na colônia, o rei procurava fazer adaptações dos pressupostos jurídicos do direito espanhol, sobretudo do documento Leis das Índias (CARNEIRO DA CUNHA, 1992).

Apenas no século XVII, Portugal editou um documento específico para os povos autóctones do Brasil. Assim, o Diretório dos Índios, documento formulado no período pombalino, em 1755, foi o principal documento que tratava de políticas para a Região Amazônica, notadamente, para as províncias do Grão-Pará e Maranhão. Mais tarde, essa legislação indigenista foi pragmática e se aplicava para todo o território nacional, assim deixando profundas marcas de morticínio no coração das culturas tradicionais originárias.

O Diretório dos Índios, em 1755, não alcançou toda a extensão da Colônia. A política indigenista colonial ficou delimitada a uma parte da população autóctone localizada na Região Norte do Brasil; para os demais, a condição era de omissão e de invisibilidade dos indígenas por parte da metrópole lusitana. Portanto, não havendo qualquer proteção oficial, a ação política contra os povos ficava à mercê dos interesses e da ação dos aventureiros que capturavam e escravizavam nativos para colocar à disposição do sistema colonial (CARVALHO E MELLO, 1997).

Como se pode observar, na época, o índio era visto como um "silvícola", um "habitante da selva", "bárbaro", ele não respeitava as leis da sociedade porque não conhecia a civilização. Tal condição era motivo de reprovação geral por parte dos colonizadores. O pensamento colonial acreditava na integração do autóctone como um ser totalmente "submisso", de maneira que receberia, por meio da ética religiosa e do trabalho, os valores da civilização ocidental. Dessa forma, o processo de adaptação do indígena ao modelo civilizatório levaria, principalmente a uma falsa integração nacional, já que o nativo era visto como um elemento "perigoso", "arredio", "hostil" e avesso às formas de poder e disciplina.

O Diretório dos Índios, conhecido como Diretório Pombalino (Lei de 1755), assinado por Dom José, Rei de Portugal, foi uma política indigenista de Estado com poder de organização social e pressão política sobre a vida dos ameríndios na Região Norte do Brasil. No que tange à questão das diretrizes do documento colonial, observa-se que o objetivo era aplicar fundamentalmente uma ética disciplinadora e moralizadora do nativo por meio da construção dos aldeamentos coletivos e do trabalho persistente na agricultura como forma de catequizá-los e civilizá-los. Assim, Sebastião Joseph de Carvalho Mello, mais conhecido como Marquês de Pombal, afirmava que:

Não podendo negar, que os índios deste Estado se conservaram até agora na mesma barbaridade, como se vivessem nos incultos sertões em que nasceram, praticando os péssimos e abomináveis costumes do paganismo, não só privados do verdadeiro conhecimento dos adoráveis mistérios da nossa sagrada religião, mas até das mesmas conveniências temporais que só se podem conseguir pelos meios da civilidade, da cultura, e do comércio: E sendo evidente, que as paternais providências de nosso Augusto Soberano, se dirigem unicamente a cristianizar e civilizar estes infelizes e miseráveis povos, para que saindo da ignorância e rusticidade a que se acham reduzidos possam ser úteis a si, aos moradores e ao Estado. (CARVALHO MELLO, 1997, p. 1).

O Diretório foi um grande projeto "civilizatório" que procurava extinguir o trabalho missionário nos aldeamentos, elevando-se a política de concentração de autóctones em vilas e aldeias, sobretudo na Região Sul do Brasil. A política colonial baseou-se nesse documento oficial apesar de ter sido elaborado em 1755, porém, apenas se tornou público em 1757 . O texto normativo expressou importantes aspectos da política indígena do período da história de Portugal e do Brasil intitulado pombalino. 
A legislação do período colonial foi ineficaz do ponto de vista da organização política e geográfica, já que era aplicada de forma muito localizada e atribuía aos diretores todas as funções possíveis de arregimentação de nativos para os aldeamentos, e estes deveriam produzir riquezas e pagar tributos com o fruto de seu trabalho à Coroa. No documento intitulado Diretório dos Índios, observa-se a seguinte referência aos nativos da região do Grão-Pará e do Maranhão:

Sendo também indubitável, que para a incivilidade, e abatimento dos índios, tem concorrido muito a indecência, com que se tratam em suas casas, assistindo diversas famílias em uma só, na qual vivem como brutos; faltando àquelas leis da honestidade, que se deve à diversidade dos sexos; do que necessariamente há de resultar maior relaxação nos vícios; sendo talvez o exercício deles, especialmente o da torpeza, os primeiros elementos com que os pais de famílias educam a seus filhos: cuidarão muito os diretores em desterrar das povoações este prejudicialíssimo abuso, persuadindo aos índios que fabriquem as suas casas a imitação dos brancos; fazendo nelas diversos repartimentos, onde vivendo as famílias com separação, possam guardar, como racionais, as leis da honestidade, e polícia. (CARVALHO MELLO, 1997, p. 3).

O Diretório foi extinto por Carta Régia, em 14 de setembro de 1798, ou seja, teve vigência de 43 anos de política opressora sobre os grupos originários. A validade desse documento jurídico-político, no período colonial, foi marcada pela ideologia da "guerra justa", "guerra humanitária", "aldeamentos", "intrusamento", ideologia de aproximação de transformação dos "silvícolas" em "índios aliados", "índios amigos", sobretudo desencadeada pelo estado colonial contra milhões de pessoas indefesas e inocentes em várias províncias no Brasil.

Com a extinção do Diretório dos Índios, veio a fase de indefinição política no tocante à questão indigenista por parte do governo português, por isso, foram implantados modelos emergenciais de acordo com as necessidades locais dos aldeamentos e para os índios não estabelecidos em povoações restavam as perseguições e a "guerra justa". De fato, a política ausente e ambígua do estado lusitano foi registrada pelos conflitos seguintes em relação às disputas pelas terras dos nativos em muitas regiões do país.

A continuidade da política colonial no trato com a questão dos povos autóctones no Império era previsível, sobretudo pela característica política do Estado Português de tratar desse tema específico com ambiguidade e prepotência. O fato é que não houve mudança na orientação do monarca, a não ser mais pressão social sobre os povos indígenas com a introdução de muitos decretos, alvarás e cartas régias executadas em todas as províncias durante os séculos seguintes de colonização.

\subsection{Enfoques da legislação indigenista no Império}

No que diz respeito à extinção do Diretório, como já dito, observou-se um vácuo legal em relação à legislação indígena que perdurou ao longo da primeira metade do século XIX. Entretanto, por falta de diretrizes que substituíssem o documento pombalino, este ficou valendo oficialmente nas províncias, por desconhecimento de muitos governadores provinciais do ato de anulação, até que entrasse em vigor o novo documento, intitulado de Regulamento das Missões, em 1845.

Carneiro da Cunha (1992) afirma que o Regulamento das Missões, proclamado em 1845, é o único documento indigenista geral do Império. Ela ainda lembra que tal documento era detalhado ao extremo, sendo mais um documento administrativo localizado do que um plano 
político geral. A questão era fundamentalmente a continuidade do sistema de aldeamento e a assimilação completa dos índios.

Assim, cinco anos após a implantação do Regulamento das Missões, surgiu outro texto jurídico, chamado de Lei das Terras (Lei 601, de 18/09/1850), que reafirmava a conveniência de se assentarem "hordas selvagens", termo utilizado na época para denominar coletivos indígenas. Logo, esse documento que tratava do regulamento das terras naturalmente:

[...] inaugura uma política agressiva em relação às terras das aldeias: um mês após sua promulgação, uma decisão do Império manda incorporar aos Próprios Nacionais as terras de aldeias de índios que vivem dispersos e confundidos na massa da população civilizada. Ou seja, após ter durante um século favorecido o estabelecimento de estranhos junto ou mesmo dentro das terras das aldeias, o governo usa o duplo critério da existência de população não indígena e de uma aparente assimilação para despojar as aldeias de suas terras. (CARNEIRO DA CUNHA, 1992, p. 145).

Ainda em relação à Lei de Terras, 1850, pode-se observar uma política agressiva no tocante às terras das aldeias, ou seja, diz-se que um mês após a sua promulgação, uma determinação do Império estabeleceu uma política de anexação dos territórios indígenas, onde a população local foi considerada como "misturados", "intrusados", "apoderados", sobretudo dispersos em meio à população de origem europeia e/ou luso-brasileira. Carneiro da Cunha (1992) adverte que a política oficial, desde a época do Diretório dos Índios, fixava estranhos nos contornos das áreas indígenas com o objetivo de integrar física e socialmente os nativos ao resto da população nacional, sobretudo prevendo incorporar os autóctones à sociedade nacional que estava para nascer dessas matrizes socioculturais. Além disso, havia, por parte de setores conservadores da burguesia nascente, a ideia de formação de um tipo ideal de povo brasileiro, principal substrato de uma nação viável com forte inclinação para os valores da civilização ocidental.

A primeira Constituição do Império do Brasil, outorgada pelo Imperador D. Pedro I, em 24 de março de 1824, foi omissa sobre o tratamento a ser dispensado à população indígena; apenas veio a tratar do assunto após a adoção do Ato Adicional de 1834, que, entre as competências legislativas das Províncias, não passava da tarefa de dispor sobre a "catequese e civilização dos indígenas", algo profundamente conservador e autoritário (LACERDA, 2008, p. 13).

De fato, a Carta de 1824, assim como as que a sucederam, não contou com nenhum tipo de participação social na sua elaboração, deixando para o futuro a responsabilidade com a questão indígena. O documento foi preparado pela nobreza togada e imposto pelo Imperador Dom Pedro I sem que fosse feita qualquer referência aos povos originários, razão maior para colocar os povos originários numa situação de invisibilidade sociocultural e política em relação à sociedade nacional.

Souza Filho (2010) afirma que o Estado Brasileiro, oriundo da Constituição de 1824, não alterou a postura política de integração do índio à sociedade nacional. Em razão disso, em 1845, o Imperador Dom Pedro II editou uma lei regulamentando especificamente a relação índios-Estado, isto é, o Decreto 426, de 24/07/1845, que, segundo o autor, criava uma estrutura administrativa para cuidar das questões indígenas, sobretudo com "[...] a designação de funcionários e competências de proteção e aldeamento dos povos encontrados, o Estado entregava à Igreja grande parte da responsabilidade de atendimento a estes povos" (SOUZA FILHO, 2010, p. 88).

Ainda no tocante à questão dos atos administrativos do imperador, não tardou muito, em 1850, segundo Souza Filho, surgiu a preocupação com as áreas pertencentes aos indígenas. Para 
o autor, a Lei 601, de 18/09/1850, inovou na questão da legislação sobre a ocupação territorial brasileira, especialmente revogando definitivamente o ordenamento jurídico português antes utilizado no Brasil. Tal medida abriu espaço para elaboração de conceitos e termos jurídicos que servem e se utilizam, até hoje em dia, como: "[...] terras devolutas, registro de imóveis e reservas indígenas." Ademais, sem abandonar a visão integracionista conservadora do período imperial, o autor ainda afirma que "[...] a legislação brasileira avançava no sentido de garantir aos índios 'restantes' alguns direitos sobre as terras que ocupavam. A prática do Estado, porém, continuava a trabalhar contra" (SOUZA FILHO, 2010, p. 88).

Durhan (1983, p. 14) considera que, mesmo após a independência de Portugal, as elites e o Estado brasileiro cultivavam uma imagem negativa do nativo, consideravam o índio como "[...] a negação do progresso e do desenvolvimento", isto é, um sinal de atraso para a Nação. Como tal, torná-lo invisível e sem leis específicas de proteção o conduziria depressa à categoria de camponês e de pequeno agricultor. A combinação política desses fatores levaria gradualmente os autóctones a se integrarem a sociedade nacional.

\subsection{A política integracionista do período republicano}

A Proclamação da República em nada alterou a realidade dos povos indígenas já integrados à sociedade nacional. Eles continuaram sendo massacrados, e os seus territórios, devastados pelo avanço dos valores da civilização industrial. Comenta-se que, na construção da estrada de ferro Noroeste do Brasil, no Estado de São Paulo, no início do século, quase foi levado ao extermínio o grupo Kaingang da região, segundo alguns estudos antropológicos. Nessa direção de análise, Coelho dos Santos (1989, p. 14) afirma que: "A violência foi tal que um relato da época noticiava que o divertimento dos trabalhadores da estrada [de ferro] aos domingos era passarinhar índio".

Mais tarde, com a vinda da Constituição Republicana de 1891, esperavam-se mudanças na cultura política nacional, sobretudo na questão das leis indígenas. Entretanto a Carta de 1891 não avançou nas questões dos direitos das populações originárias a ponto de omitir qualquer linha escrita nos textos constitucionais sobre a dívida histórica com os povos nativos. Ela reproduziu, mais uma vez, o conservadorismo das elites dominantes brasileiras herdado do colonialismo lusitano. Como tal, a Constituição em vigor não contou com nenhuma participação popular nas discussões que levaram à sua elaboração final, motivo pelo qual omitiu mais uma vez a questão da inserção dos direitos indígenas na ordem nacional. Desse modo, de acordo com Lacerda (2008), as contribuições sobre,

[...] o tratamento a ser dado aos povos indígenas continuava a sair de restritos círculos das elites, como a proposta do Apostolado Positivista. Este propunha dividir o status jurídico dos índios entre "Estados Ocidentais Brasileiros", compostos por grupos miscigenados, e "Estados Americanos Brasileiros", compostos por "hordas fetichistas". Mas a primeira Carta constitucional da República, a exemplo da do Império, também sequer mencionou a existência de indígenas em território brasileiro. (LACERDA, 2008, p. 13).

Como se pode notar, os positivistas tinham uma proposta constitucional no sentido de garantir os direitos específicos aos povos indígenas, em 1891, porém, foi totalmente contestada pelos grupos conservadores ligados ao processo de expansão e colonização. Afinal, o programa nem chegou a ser posto em votação devido à resistência política dos setores dominantes. $O$ Apostolado Positivista do Brasil defendia um plano que procurava trazer o nativo à sociedade 
nacional de maneira gradual, incorporando o indígena ao processo de modernização, o qual perpassava todos os setores da sociedade brasileira.

No período republicano, prosperaram as ideias de uma sociedade industrial fundamentada numa matriz racial branca de origem europeia. Passada essa fase inicial da república brasileira, muito pouco se avançou no que diz respeito às questões sociais e políticas referentes aos índios. O Estado brasileiro prolongava a cultura da indiferença, da "invisibilidade" em relação às populações étnicas.

Aliado a essa questão da negação dos direitos dos índios na aplicação jurídica, Carneiro da Cunha (2008, p. 155), analisando a tradição do sistema jurídico brasileiro diz que: "[...] Constituições brasileiras, desde 1934, 1937, em 1946, em 1967 e em 1969, todas elas têm um artigo, um ou mais artigos até, sobre os Direitos Territoriais Indígenas. As terras ocupadas pelos índios são de sua posse permanente, é o texto atual do art. 198. São, portanto, direitos históricos".

Posta a questão, é de se dizer que, entre a Constituição de 1891 e a Carta de 1934, foram aproximadamente quarenta e três anos sem tocar na questão dos direitos dos povos indígenas por parte da República brasileira. Como se não bastasse, o ideal de branqueamento da população nacional, essencial ao positivismo cientificista que tanto marcou os círculos militares republicanos da época, não admitia o reconhecimento de qualquer tipo de diversidade que fizesse questionar o conceito de unidade nacional então perseguido (LACERDA, 2008).

Depois de quase quatro séculos de colonialismo português, o Estado brasileiro, temendo o avanço da organização do movimento indígena, buscou atrelar a política indígena ao Serviço de Proteção ao Índio e Localização de Trabalhadores Nacionais (SPILTN), criado pelo Decreto 8.072, de 20 junho de 1910, pretendendo novamente enquadrar o indígena na cultura europeia, agora sob a nova ótica: índio trabalhador nacional. Em razão disso, aquele órgão foi transformado posteriormente, em 1918, no Serviço de Proteção ao Índio (SPI), que deu continuidade à política assimilacionista e integracionista do indígena à sociedade nacional. Assim, conforme alguns estudiosos, em meio às acusações de corrupção, o órgão foi extinto, em 1966, e substituído pela Fundação Nacional do Índio (Funai). Essas organizações nortearam a política indigenista no século XX numa única direção: integrar o índio à comunidade nacional (COELHO DOS SANTOS, 1989; CARNEIRO DA CUNHA, 1992; SOUZA LIMA, 1992; LACERDA, 2008; SOUZA FILHO, 2010; RODRIGUES, 2011; SANTOS FILHO, 2012).

Assim, a Constituição de 1934, conhecida e cortejada como sendo a mais democrática até aquela etapa política, não conseguiu espelhar os interesses amplos da sociedade em seus diversos setores, sobretudo no tocante aos direitos efetivos das populações autóctones. Como se não bastasse, ela foi elaborada e passou a vigorar sem que houvesse participação popular na sua preparação, assim refletindo os acordos políticos das oligarquias regionais estabelecidas nas demais regiões do país (CARNEIRO DA CUNHA, 2008).

Não obstante o processo de preparação e composição da carta jurídica, pode-se dizer que foi na Constituição de 1934 que surgiu a primeira menção à existência de índios no país e à questão das terras dos povos originários. A referência acanhada aos povos autóctones, na Carta de 1934, não trouxe nada de relevante, aliás, reproduziu os velhos esquemas das oligarquias dominantes do País. Por isso, o esboço do documento fazia alusão aos indígenas como indivíduos portadores de identidades próprias a serem respeitadas, antes, porém, deveriam ser submetidos a uma condição passageira de "silvícola", "habitante da selva", que haveriam de ser conduzidos pelas mãos do Estado ao seio da "comunhão nacional", logo, ao espectro 
da civilização. Em virtude disso, a Constituição Federal de 1934 difundia visivelmente a política integracionista no:

Art. 5.․: Compete privativamente à União:

$[\ldots]$

XIX - Legislar sobre:

m) Incorporação dos silvícolas à comunhão nacional.

A política integracionista era algo irreversível e admitido por todos os setores como uma condição para se atingir um projeto político de construção de Estado-nação. Para completar tal promessa, restava apenas incorporar os autóctones à sociedade nacional, algo que o Apostolado Positivista já propagava antes mesmo da Constituição de 1891. Com a mudança dos processos políticos no Brasil e no mundo ocidental, o fascismo se propagou nacionalmente, e a Constituição de 1934 logo foi revogada e substituída pelo documento autoritário de 1937. Este, de natureza política repressiva, chegou a flertar com o nazi-fascismo, razão pela qual nem tocava no assunto dos direitos dos índios.

Assim, a política indigenista brasileira oscilava constantemente, porém, mais uma vez, manifestava contradição e hipocrisia, resultado do modelo colonial português de flutuações jurídicas no tocante à questão nacional dos grupos étnicos. Por isso, mesmo o único artigo que se referia aos povos ameríndios foi ignorado devido aos rumos políticos que o país adotava em relação à nação. Lacerda (2008, p. 14) assinala que:

À época o mundo estava à beira da II Grande Guerra. Setores influentes do Estado Novo não conseguiam esconder uma forte simpatia pelos sentimentos de intolerância que marcavam o nazismo na Alemanha e o fascismo na Itália. Em relação à questão indígena, embora contivesse um dispositivo prevendo o tratamento a ser dispensando às terras indígenas, a [constituição] de 1937 omitiu-se quanto ao lugar dos povos indígenas na sua relação com o Estado brasileiro e sua sociedade. Com tal omissão, não previu a incorporação dos índios à comunhão nacional, mas também não cuidou do reconhecimento de suas identidades próprias.

Como se pode observar, passado o período ditatorial de Getúlio Vargas, veio a Constituição de 1946, com um texto considerado avançado, entretanto, em sua origem, não espelhava a participação da sociedade civil, sobretudo das camadas populares e das minorias étnicas. No que se refere à questão dos direitos dos autóctones, cuja participação sempre fora excluída dos regimentos, declarações e escritos jurídicos anteriores, a Carta de 1946 seguiu a mesma regra dos diplomas precedentes. Esta apenas reproduziu o artigo do texto constitucional de 1934, que pregava a legislação sobre a incorporação dos "silvícolas" à comunhão nacional. Convém notar, outrossim, que a tese da assimilação e integração dos originários à sociedade branca continuava circulando nos meios jurídico-políticos como uma tendência aceitável e culturalmente unidirecional.

De acordo com Carneiro da Cunha (2008), a proposta integracionista adotada pela Constituição de 1967 sintonizava com a perspectiva integracionista predominante no plano internacional no que tange aos povos autóctones. Ou seja, ela flertava com a tendência mundial de buscar os valores e os costumes da civilização europeia para impulsionar o desenvolvimento e progresso à custa do padecimento dos grupos étnicos. Nesse sentido, a Emenda Constitucional n. 1 de 1969 novamente corroborava com as prerrogativas assimilacionistas dos documentos jurídicos oficiais de 1934 e 1946. 
A nova Constituição, publicada oficialmente em 24 de fevereiro de 1967, sintonizou, então, com a perspectiva também integracionista predominante no plano internacional em relação aos povos indígenas. Conforme Santos Filho (2012), na vigência desse documento, foi editada a Lei 5.371, de 05 de dezembro de 1967, que tratou da extinção do SPI (Serviço de Proteção ao Índio), totalmente desgastado do ponto de vista político-administrativo pela inoperância em relação à questão dos povos originários. Em razão da extinção do SPI, o governo concebeu outro órgão federal que tratasse da questão indígena nos moldes disciplinadores da antiga entidade rondoniana. Assim, com base no argumento de proteção à vida do autóctone, foi apresentada a Funai, órgão do governo brasileiro, que tem por fim até hoje: "[...] Aplicar a política em prol do índio no território nacional; zelar pelo patrimônio indígena; fomentar estudos sobre populações indígenas que vivem em território brasileiro e garantir sua proteção; demarcar e proteger as terras tradicionalmente ocupadas pelos índio" (SOUZA FILHO, 2010, p. 43). Vale ressaltar que a realidade brasileira estava mergulhada no autoritarismo político, de sorte que haveria pouco espaço para as culturas locais se não se aceitassem as imposições do progresso econômico imposto pelo modelo de desenvolvimento rumo ao interior do Brasil.

Pouco tempo depois, em consonância com a Emenda Constitucional n. 1/69, a Lei n. 6.001, de 19 de dezembro de 1973, criava o "Estatuto do Índio", cujo propósito era cuidar e tutelar o indígena sob o comando diretivo da instituição Funai. Com base nesse regulamento jurídico, a entidade federal de assistência ao índio veio atuar sobre os povos autóctones do País. O Estatuto do Índio é um marco jurídico disciplinador dos povos originários no que diz respeito à vida dos índios nos territórios tradicionais (COELHO DOS SANTOS, 1989; CARNEIRO DA CUNHA, 1992; SOUZA LIMA, 1992; SOUZA FILHO, 2010; RODRIGUES, 2011; SANTOS FILHO, 2012).

É bem verdade que, historicamente, não houve nenhum instrumento tão regulador, com igual poder de força, que cuidasse da assistência e "proteção" dos indígenas de maneira tão uniforme no Brasil. Sabe-se que nem mesmo o famigerado e contraditório Diretório dos Índios foi tão poderoso a ponto de alcançar quase todas as regiões em 1755, assim como o Regulamento das Missões, em 1845. Convém notar que esses dois instrumentos disciplinadores, introduzidos ainda sob o domínio português, foram excessivamente oscilatórios e segmentados, uma vez que o impacto não tocava, muitas vezes, todas as regiões.

De acordo com Souza Filho (2004, p. 77),

O exemplo mais claro da dificuldade de serem regulamentados os direitos coletivos estabelecidos na Constituição é a história da lei geral sobre os povos indígenas no Brasil. O antigo Estatuto do Índio, de 1973, ainda em vigor, tem um nítido corte individualista, integracionista e juridicamente civilista, por isso mesmo atribui às instituições jurídicas de proteção um caráter provisório, isto é, até que os índios individualmente passem à categoria de integrados à comunhão nacional, como cidadãos sem qualquer outra qualificação ou diferenciação étnica, isto é, deixem de ser índios.

Assim, para Durhan (1983, p. 14), a legislação protetora deve ser interpretada:

No caso dos índios, [...] como um recurso retórico indispensável para legitimar o caráter nacional do Estado integrando o índio como súdito sob a ficção da proteção tutelar. A contradição que isso cria em relação aos interesses econômicos efetivamente representados no Estado tem sido resolvida, na prática, através do subterfúgio de reconhecer direitos formais e permitir seu desrespeito sistemático; ideologicamente, através da elaboração de uma teoria de cristianização, 
civilização ou integração que, defendendo a preservação física dos índios, justifica sua destruição, enquanto sociedade e enquanto cultura, em nome do progresso.

No que tange à repressão por parte do Estado em relação aos movimentos sociais e políticos no Brasil, durante os anos de 1970, ela não impossibilitou que o movimento indígena buscasse a organização e a articulação com outros setores da sociedade não-indígena apesar de as lideranças estarem sob constante vigilância e disciplinamento político.

\section{O PROTAGONISMO INDÍGENA}

Neves (2004) afirma que, nos anos de 1970, o movimento indígena estava no período das grandes assembleias indígenas, isto é, nas descobertas mútuas e trocas de experiências e informações sobre os contextos interétnicos enfrentados por cada povo. Era a época em que os grupos indígenas passavam a se conhecer politicamente melhor dentro do contexto sociocultural brasileiro, porque sofriam, até então, com o isolamento social e político imposto pelo estado nacional.

Como se pode notar, Neves (2004) destaca o florescimento da organização indígena nos anos de 1970, com muita troca de informações importantes no que tange à organização social e à realidade enfrentada por cada povo em seus diferentes contextos étnicos. O primeiro momento pautou-se pelo conhecimento e permutas de práticas organizativas, motivo pelo qual levou o autor afirmar que: "[...] É nesta fase que a troca de experiência e problemas vividos dá origem a um senso de solidariedade indígena [unidade] nunca antes vivenciado, constituindo um espírito de corporação, que é a marca desta fase e que passou a ser a base de todas as mobilizações indígenas" (NEVES, 2004, p. 89).

Ortolan-Matos (2006), referindo-se àquele momento, intitulou-o de configuração "pan-indígena" ou "supraétnica" porque havia o entendimento de que a causa indígena era uniforme e ampla de sorte que atingiria todos os grupos igualmente, porém, mais tarde, essa concepção foi revista, e o termo foi modificado. Para ela, foi uma ocasião importantíssima que consistiu na organização dos grupos indígenas a partir de uma identidade chamada supraétnica. Por isso, a participação dos índios foi acontecendo via assembleias organizadas, sobretudo por agentes externos como entidades de defesa dos direitos indígenas e organizações religiosas. O Conselho Indigenista Missionário (Cimi) teve um papel fundamental no processo de articulação dos diferentes povos em todo território nacional. É importante salientar que a atuação e a parceria dessa instituição evangelizadora foram importantíssimas na organização e conscientização política das lideranças indígenas nos diferentes territórios. Além disso, o processo de trocas de experiências resultou, num primeiro plano, na articulação do movimento e, num segundo momento, na criação, em 1980, da União das Nações Indígenas (UNI), organização de defesa dos direitos dos povos originários de expressão nacional.

No tocante às assembleias interétnicas, ficou evidente a necessidade de uma articulação permanente e de caráter nacional. De fato, os índios sozinhos eram fracos; mas, juntos, os indígenas seriam fortes e poderiam ser ouvidos pelas autoridades governamentais, já que viviam sob o regime de tutela por parte da entidade indigenista Funai. Se o índio, para sair de seu espaço a fim de tratar de qualquer assunto pessoal na cidade, deveria ter autorização prévia do chefe do posto da Funai, imagine-se se a justificativa fosse para participar de eventos de natureza política organizacional do movimento indígena. De qualquer maneira, os relatos sobre perseguições e 
prisões arbitrárias de lideranças são inúmeros, apesar de as ameaças e intimidações não desencorajarem as expectativas de muitos defensores indígenas, a exemplo do líder indígena Marçal Guarani e do ex-cacique Kaingang Ângelo Cretã, entre outros (PREZIA, 2006; HELM, 1982).

Convém notar que o panorama dos anos 1980 na política do Brasil era marcado por inúmeras mobilizações que exigia o fim da ditadura e a volta ao Estado democrático de Direito. As manifestações e as lutas políticas pela redemocratização desencadearam profundas mudanças no contexto nacional; estenderam-se ao movimento indígena, resultando alterações na correlação de forças entre os atores sociais envolvidos no trato da questão indígena, sobretudo na preparação e organização dos povos indígenas na pré-constituinte.

Ainda em relação aos anos de 1980, Neves (2004) afirma que o movimento indígena transformou-se e/ou deslocou-se da concepção antes defendida de pan-indigenismo (generalização) para o de atomização das lutas em diversos segmentos (Ongs, associações, entidades de defesas dos direitos humanos). O autor assinala que essa fase de atomização experienciou a multiplicação das organizações e a afirmação das alianças estratégicas diferentemente do que vinha acontecendo no contexto latino-americano.

Dessa maneira, a fase dos anos de 1980 foi de grande importância para a afirmação da causa indígena, visto que as mobilizações étnicas possibilitaram que as próprias lideranças se fizessem representar por si próprias em questões políticas e jurídicas perante o Estado e à sociedade brasileira. É um passo importante para os líderes atuarem efetivamente na elaboração do desejado Capítulo VIII, "Dos Índios", da CF/88, em que trata de dois Artigos importantíssimos para os coletivos indígenas, por exemplo, no Artigo 231. "São reconhecidos os índios sua organização social, costumes, línguas, crenças e tradições, e os direitos originários sobre suas terras que tradicionalmente ocupam, competindo à União demarcá-las, proteger e fazer respeitar os seus bens" (CF, 1988, 143).

Ademais, no Artigo 232 da CF (1988, p. 144) afirma que: "Os índios, suas comunidades e organizações são partes legítimas para ingressar em juízo em defesa de seus direitos e interesses, intervindo o Ministério Público em todos os atos do processo".

Até então, tratados pela legislação como "relativamente incapazes" e subordinados à tutela do Estado, aos povos indígenas era reservado o conformismo e a alienação, sendo representados por órgãos públicos através de porta-vozes de seus anseios e reivindicações. As entidades indigenistas eram normalmente os legítimos intermediários dos autóctones nas esferas públicas.

Como se não bastasse, o Estado não abdicava da questão da assimilação e integração, devido a isso e às organizações sociais de base, surgiram os porta-vozes dos movimentos indígenas que falavam em causa própria, contrariando o poder de tutela que sempre foi assegurado ao Estado brasileiro. Antes da Constituição Federal de 1988, o movimento indígena sobrevivia a partir de uma "ilegalidade tácita"; após 1988, com a promulgação da nova Carta Magna, as organizações indígenas adquirem status de organizações sociais, legalmente aceitas e legítimas representantes dos povos originários. Então, pela primeira vez, no Brasil, os índios podem exercer sua voz ativa e defender eles mesmos os seus interesses (NEVES, 2004).

Ademais, pela primeira vez na história do país, os povos autóctones são construtores dos processos e estão organizados como grupo de pressão social e política na pré-constituinte de 1987/88. Nesse período, foi criado uma subcomissão especial com a participação apenas de representantes das nações para ler e sugerir modificações no texto constitucional. Vale ressaltar a conquista (barganha política) dos inúmeros grupos participantes, ou seja, não aceitaram ser 
representados por partidos políticos nem por intermediários nas subcomissões que tratavam dos assuntos relacionados aos seus direitos políticos e sociais.

\subsection{A conquista dos direitos e a adoção de acordos internacionais}

A Constituição Federal ${ }^{2}$ de 1988 tem sido um grande referencial na luta indígena, pois nela estão as diretrizes principais para a implementação da política indigenista brasileira. Pode-se observar, no Capítulo VIII- "Dos Índios", conquistas importantes a saber: primeiro, o direito de permanecer indígena, cultivar sua organização social, costumes, línguas, crenças e tradições; segundo, a possibilidade dos grupos serem parte legítima na defesa de seus direitos. Isto é, as comunidades podem ingressar em juízo em defesa de seus direitos e interesses, intervindo o Ministério Público em todos os atos do processo.

Esses dois dispositivos constitucionais vêm romper com a lógica integracionista e de tutela indígena ao longo dos quinhentos anos de dominação. Ou seja, os povos indígenas podem participar, discutir e organizar-se politicamente sem precisar pedir autorização ao Estado. Além disso, é importante destacar que a política indigenista, sob hipótese alguma, constrangerá o índio a deixar a sua tradição e cultura para integrar-se ao Estado-nação como no passado.

Aliado a essa visão jurídica acerca da garantia e proteção da integridade do sistema cultural dos povos indígenas, Souza Filho (2010, p. 104) assinala que essa concepção normativa é nova, importante e juridicamente revolucionária, porque vem romper com a repetida visão integracionista de toda a história política de extermínio do indígena no Brasil. Dessa maneira, como bem assinala o autor, a partir de 5 de outubro de 1988 é que: "[...] o índio, no Brasil, tem o direito de ser índio".

De acordo com Santos Filho (2012, p. 45), a Constituição de 1988 reconhece o índio como 'diferente', sem que essa diferença possa ser confundida com 'incapacidade'; reconhece a 'capacidade' do índio para ingressar em juízo na defesa de seus direitos, sem depender da "intermediação - alterou substancialmente a natureza do regime tutelar indígena: primeiro, esse regime passou a ter natureza 'protetiva'; segundo, passou a ter estatura constitucional." Portanto, para o autor, a proteção 'constitucional' impede ataques pela via do processo legislativo ordinário.

$\mathrm{O}$ avanço do debate sobre os marcos regulatórios dos direito indígenas na CF/88 abriu espaço para a política de adoção de alguns documentos internacionais; é o caso da Convenção no 169 da Organização Mundial do Trabalho (OIT), sobre Povos Indígenas e Tribais, adotada em Genebra, em 27 de junho de 1989, considerando que o governo brasileiro depositou o instrumento de ratificação junto ao Diretor Executivo da OIT em 25 de julho de 2002. Além desse documento regulatório e de importância ímpar para os povos autóctones, o Brasil adotou e ratificou, em 2008, outro texto importante das Nações Unidas (ONU), a Declaração das Nações Unidas sobre os Direitos dos Povos Indígenas.

Os dois documentos supracitados trataram da questão dos povos originários e tradicionais de maneira respeitosa e denunciaram que quaisquer doutrinas, políticas e práticas baseadas na superioridade de determinados povos e/ou indivíduos, ou que a defendam alegando razões de origem nacional ou diferenças raciais, religiosas, étnicas ou culturais, são racistas, cientificamente falsas, juridamente inválidas, moralmente condenáveis e socialmente injustas (CONVENÇÃO 169/ OIT, 2011; DECLARAÇÃO DAS NAÇÕES UNIDAS, 2008).

\footnotetext{
${ }^{2}$ Foi promulgada a oitava Constituição do Brasil, chamada Constituição Cidadã, no dia 5 de outubro de 1988.
} 
Interessante notar que no texto da Declaração das Nações Unidas, aprovada pela ONU, em 2007, fica explícito, nos primeiros artigos, a possibilidade dos povos originários viverem conforme suas tradições e costumes ancestrais, além do mais, eles são autônomos para reforçar suas próprias instituições sociais e políticas de acordo com seus desejos. Assim, a Declaração estabelece no:

Artigo III - Os povos indígenas têm direito à autodeterminação. Em virtude desse direito determinam livremente sua condição política e buscam livremente seu desenvolvimento econômico.

Artigo IV - Os povos indígenas, no exercício de seu direito à autodeterminação, têm direito a autonomia ou ao autogoverno nas questões relacionadas a seus assuntos internos e locais, assim como a disporem dos meios para financiar suas funções autônomas.

Artigo $\mathbf{V}$ - Os povos indígenas têm o direito de conservar e reforçar suas próprias instituições políticas, jurídicas, econômicas, sociais e culturais, mantendo ao mesmo tempo seu direito de participar plenamente, caso o desejem, da vida política, econômica, social e cultural do Estado.

Artigo $\mathbf{X}$ - Os povos não serão removidos à força de suas terras ou territórios. Nenhum translado se realizará sem o consentimento livre, prévio e informado dos povos indígenas interessados e sem um acordo prévio sobre uma indenização justa e equitativa e, sempre que possível, com a opção do regresso. (ONU, 2008, p. 7-9)

É de se observar que as diretrizes desses documentos são instrumentos importantíssimos atualmente nos discursos dos líderes indígenas, pois muitos deles são sabedores e participantes da elaboração desses instrumentos. $O$ artigo $X$ traz um dispositivo relevante que é a consulta livre, prévia e informada que se torna arma importante utilizada pelo movimento indígena para se contrapor a invasão de seus territórios, para explorar minérios, implementação da agricultura e do agronegócio, construções de barragens e de usinas hidrelétricas em suas terras tradicionais.

De fato, apenas a partir da CF/88, podemos visualizar uma discussão jurídica em torno dos direitos das populações indígenas e tradicionais consagrados, sobretudo pelas pressões do movimento indígena que já atuavam há décadas no sentido da construção e afirmação dos seus direitos na nova Constituição. A organização da sociedade civil foi fundamental para o acesso a espaços dentro da pré-constituinte, no sentido de colocar os temas históricos na agenda de discussão e, posteriormente, nos eventos internacionais.

\section{CONSIDERAÇÕES FINAIS}

Os diversos documentos apenas refletiam o pensamento do colonizador a respeito dos povos originários, assim, as leis portuguesas se estendiam para a colônia brasileira, ou seja, as mesmas determinações jurídicas se aplicavam aqui sem pensar na realidade local. Ademais, outros instrumentos importantes como Cartas Régias, Alvarás, Decretos e Estatutos foram aplicados implacavelmente aos povos autóctones.

Durante o processo de construção da sociedade e do Estado nacional, os povos indígenas foram totalmente excluídos das principais legislações e documentos jurídicos brasileiros. Assim, os nativos considerados silvícolas deveriam ser catequizados, disciplinados e incorporados paulatinamente à civilização nacional.

No tocante à questão da legislação indigenista, ainda é preciso lembrar que o discurso do Estado brasileiro é de incorporação dos povos nativos à sociedade nacional. Ademais, mesmo interditado pela CF/1988, ainda continua desrespeitando as conquistas jurídico-político das po- 
pulações nativas a ponto de não respeitar os próprios documentos dos quais é signatário, por exemplo, Convenção 169/OIT e a Declaração das Nações Unidas sobre os Direitos dos Povos Indígenas da ONU.

Além disso, não diferentemente do passado colonial em que a legislação era oscilatória, contraditória, hoje o Estado continua agindo de maneira indiferente para com as demandas indígenas, sobretudo em relação à demarcação de suas terras. E ainda mais, não vem respeitando os acordos e as deliberações nacionais e internacionais como o direito à consulta livre, prévia e informada e o direito à autodeterminação dos povos indígenas.

\section{REFERÊNCIAS}

BRASIL. Constituição (1988). Constituição da República Federativa do Brasil de 1988. 31. ed. São Paulo: Saraiva, 2003.

CARNEIRO DA CUNHA, Manuela. Introdução a uma história indígena. In: História dos índios no Brasil. 2. ed. São Paulo: Companhia das Letras, 1992.

. Falam os aliados da causa indígena. In: LACERDA, Rosane. Os povos indígenas e a Constituinte: 1987-1988. Brasília: CIMI, 2008. p. 154-7.

CARVALHO E MELLO, Sebastião Joseph. Diretório dos índios (1775). In: ALMEIDA, Rita H. de. O diretório dos índios: um projeto de "civilização" no Brasil do século XVIII. Brasília: UnB, 1997.

COELHO DOS SANTOS, Sílvio. Povos indígenas e a Constituinte. Florianópolis: Editora da UFSC, 1989.

DURHAM, Eunice R. O lugar do índio. In: VIDAL, Lux (Coord.). O índio e a cidadania. São Paulo: Brasiliense, 1983. p. 11-9.

FUNDAÇÃO NACIONAL DO ÍNDIO (FUNAI). Portal do cidadão - povos indígenas. Disponível em: <http:// www.funai.gov.br>. Acesso em: 3 abr. 2012.

HELM, Cecilia Maria Vieira. A terra, a usina e os índios do P. I. Mangueirinha. In: COELHO DOS SANTOS, Sílvio (Org.). O índio perante o direito: ensaios. Florianópolis: Editora da UFSC, 1982. p. 129-42.

LACERDA, Rosane Freire. Os povos indígenas e a Constituinte: 1987-1988. Brasília: CIMI, 2008.

NAÇÕES UNIDAS (ONU). Declaração das Nações Unidas sobre os Direitos dos Povos Indígenas. Rio de Janeiro: UNIC Rio, 2008. Disponível em: <http://www.un.org/esa/socdev/unpfii/documents/DRIPS_pt.pdf>. Acesso em: 1음 ago. 2012.

NEVES, Lino João de O. Olhos Mágicos do Sul (do Sul): lutas contra-hegemônicas dos povos indígenas no Brasil. In: SANTOS, Boaventura de Sousa (Org.). Reconhecer para libertar: os caminhos do cosmopolitismo multicultural. Porto: Edições Afrontamentos, 2004. p. 87-116.

ORGANIZAÇÃO INTERNACIONAL DO TRABALHO (OIT). Convenção $n .169$ sobre povos indígenas e tribais e Resolução referente à ação da OIT. 5. ed. Brasília: OIT, 2011.

ORTOLAN-MATOS, Maria Helena. Rumos do movimento indígena no Brasil contemporâneo: experiências exemplares no Vale do Javari. 2006. 244f. Tese (Doutorado em Ciências Sociais) -Instituto de Filosofia e Ciências Humanas, Universidade Estadual de Campinas (Unicamp), Campinas, SP, 2006.

PERRONE-MOISÉS, Beatriz. Índios livres e índios escravos: os princípios da legislação indigenistas do período colonial: séculos XVI a XVIII. CARNEIRO DA CUNHA, Manuela (Org.). História dos índios no Brasil. 2. ed. São Paulo: Companhia das Letras, 1992. p. 115-32.

PREZIA, Benedito. Marçal Guarani: a voz que não pode ser esquecida. São Paulo: Expressão Popular, 2006. RODRIGUES, Cíntia Régia. O positivismo, o estado nacional e as populações fetichistas no Brasil. In: SIMPÓSIO NACIONAL DA ANPUH, 26., 2011, São Paulo. Anais eletrônicos... São Paulo: ANPUH-SP, 2011.

SANTOS FILHO, Roberto L. dos. Apontamentos sobre o direito indígena. Curitiba: Juruá, 2012. 
SOUZA FILHO, Carlos F. M. de. O renascer dos povos indígenas para o direito. Curitiba: Juruá, 2010. Multiculturalismo e direitos coletivos. In: SANTOS, Boaventura de Sousa (Org.). Reconhecer para libertar: os caminhos do cosmopolitismo multicultural. Porto, Portugal: Afrontamento, 2004. p. 57-86.

SOUZA LIMA, Antonio C. de. O governo dos índios sob a gestão do SPI. In: CUNHA, Manuela C. da (Org.). História dos índios no Brasil. 2. ed. São Paulo: Companhia das Letras, 1992. p. 155-72.

THOMAS, George. Política indigenista dos portugueses no Brasil 1500-1640. São Paulo: Loyola, 1982.

\section{Sobre o autor:}

Antonio Cavalcante Almeida: Doutor em Ciências Sociais pela Pontifícia Universidade Católica de São Paulo (PUC-SP). Mestre em Sociologia Política pela Universidade Federal de Santa Catarina (UFSC). Graduado em Ciências Sociais pela Universidade Federal do Ceará (UFC). Professor de Sociologia do Ensino Médio Técnico em Automação Industrial, Instituto Federal Catarinense. E-mail: antoniocavalcant@hotmail.com 